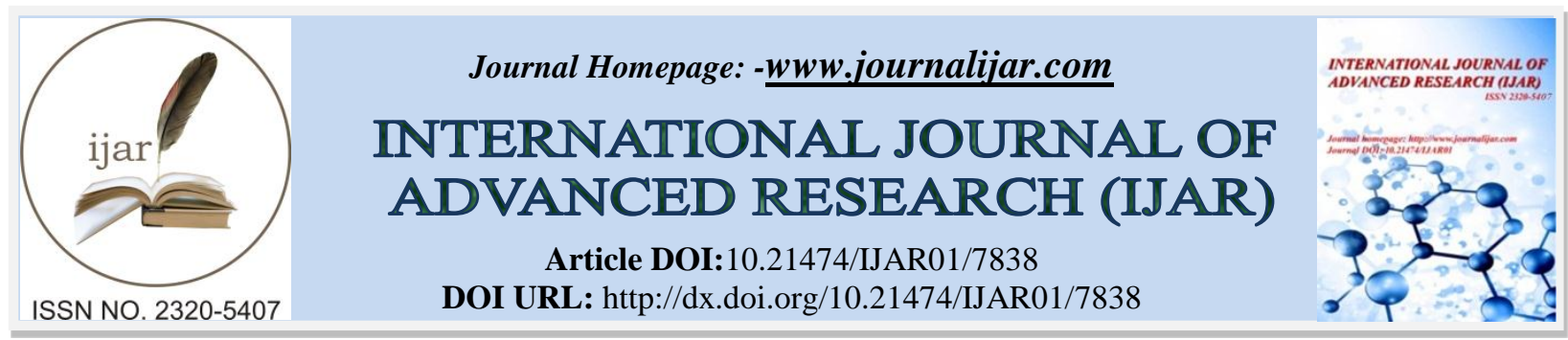

RESEARCH ARTICLE

\title{
EVALUATION OF ECOTOXICAL RISKS OF SOME METALLIC TRACE ELEMENTS IN LAGOON OF PORTO- NOVO IN BENIN.
}

\author{
Mickael Vitus Martin Kpessou Saizonou, Alassane Youssao Abdoul Karim, Magloire A. Nonvignon \\ Gbaguidi, Leonce Firmin Comlan Dovonon, Azim Mohamed Abibou, Samson Agossou and Henri \\ Houenoukpo Soclo.
}

Unit of Research in Ecotoxicology and Quality Study, Laboratory of Study and Research in Applied Chemistry, Polytechnical School of Abomey-Calavi, University of Abomey-Calavi, 07 BP 507 Ste Rita Cotonou, Benin.

\section{Manuscript Info} …......................

Manuscript History

Received: 8 August 2018

Final Accepted: 10 September 2018

Published: October 2018

Keywords:-

Metal, pollution, lagoon, Porto-Novo.

\begin{abstract}
The study focus on evaluation of concentrations of four Metallic Trace Element (MTE) $\mathrm{Cu}, \mathrm{Zn}, \mathrm{Mn}$ and $\mathrm{Pb}$ in the compartments of hydroaquatic system of Lagoon of Porto-Novo, located in southeastern of Benin. Levels of lead, manganese, copper and zinc in sediments, pisces and eichornia crassipes from lagoon are very important and fish from the lagoon had higher metal content and can present risk for human consumption.The highest values are $65.6 \mathrm{ppm}$ of $\mathrm{Zn}$ in fish, $11335.7 \mathrm{ppm}$ for $\mathrm{Mn}$ in eichornia crassipes and $41.5 \mathrm{ppm}$ for $\mathrm{Cu}$ in sediments. In pisces, level of $\mathrm{Pb}$, wich is most dangerous metal for human health among those analysed, reaches $22.8 \mathrm{ppm}$. The results show high levels which reflect anthropogenics impacts on the lagoon. The contamination sources would probably relate runoff, waste waters, solid waste discharges and the erosion of agricultural lands.
\end{abstract}

Copy Right, IJAR, 2018. All rights reserved.

\section{Introduction:-}

One of the major contemporary societies concerns is environment protection. Besides their physical role wich is to drain the waters coming from their wathershed while modeling the relief, the streams have a biologic role because they are the support of plant and animal communities (Teta, 2017). Streams polution has increased over time because of the importance of human activities and urbanization. Urban effluents are significant sources of metallic trace elements pollution in fresh water (Chaguer, 2013). Metallic trace elements presence in natural aquatic environments result from processes of rock alteration, atmospheric deposition and anthropogenic activities (Adeline, 2013). Aquatic animals can therefore be exposed to high concentrations of metals wich can cause adverse effects to organisms, including humans indirectly by transfert through the food chain.

With its very rich hydrographic potential in the west african region, the Republic of Benin has many fish ressources among wich tilapias occupy an important place (Sirima, 2018). The fish commonly refered to as tilapias are belong to the Cichidae family and include seven genera (Canonico, 2005) of wich 3 namely Oreochromis, Sarotherodon and Coptodon constitute, the group of fish called tilapias in tropical Africa (Leveque, 2006). The tilapias directly caught in the Porto-Novo lagoon (in Benin) constitue an important part of pisces consumed by populations and surely this is not without danger on the health because pisces from the lagoon potentially would content higher metallic trace elements content and would be unfit for human consumption. 
The aim of this study is to establish the concentrations of selected heavy metals such as $\mathrm{Cu}, \mathrm{Pb}, \mathrm{Mn}$ and $\mathrm{Zn}$ in tilapias caught in the lagoon of Porto-Novo, in eichornia crassipes (water hyacinth) and sediments from the same lagoon to assess the ecological and public health risks and to identify possible sources of the metals for future remedial actions.

\section{Material and Methods:- \\ Description of study area}

The lagoon of Porto-Novo $\left(6^{\circ} 28^{\prime} 0^{\prime \prime} \mathrm{N}\right.$ and $\left.2^{\circ} 36^{\prime} 0^{\prime \prime} \mathrm{E}\right)$ is the study area. It has a prevalence and abundance of suitable tilapias habitat. It is also invased by eichornia crassipess especially in dry season. A contol site has been selected at Lakpa located in Azowlisse (department of Oueme) on a branch of river Oueme for pisces and sediment sampling.

\section{Sampling}

Sampling was purposely done during the dry season, in January 2018, to capture the maximum levels of metals in the lagoon.

Three sites were selected for sampling eichornia crassipes and sediments directly from lagoon of Porto-Novo.

Due to the importance of these as a food source, tilapias from sites usually used by local fishermen have been prioritised for buying samples.

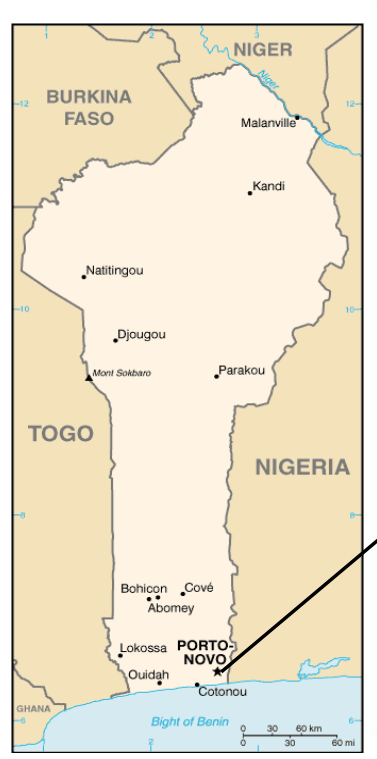

Fig 1:-Location of Porto-Novo in Benin

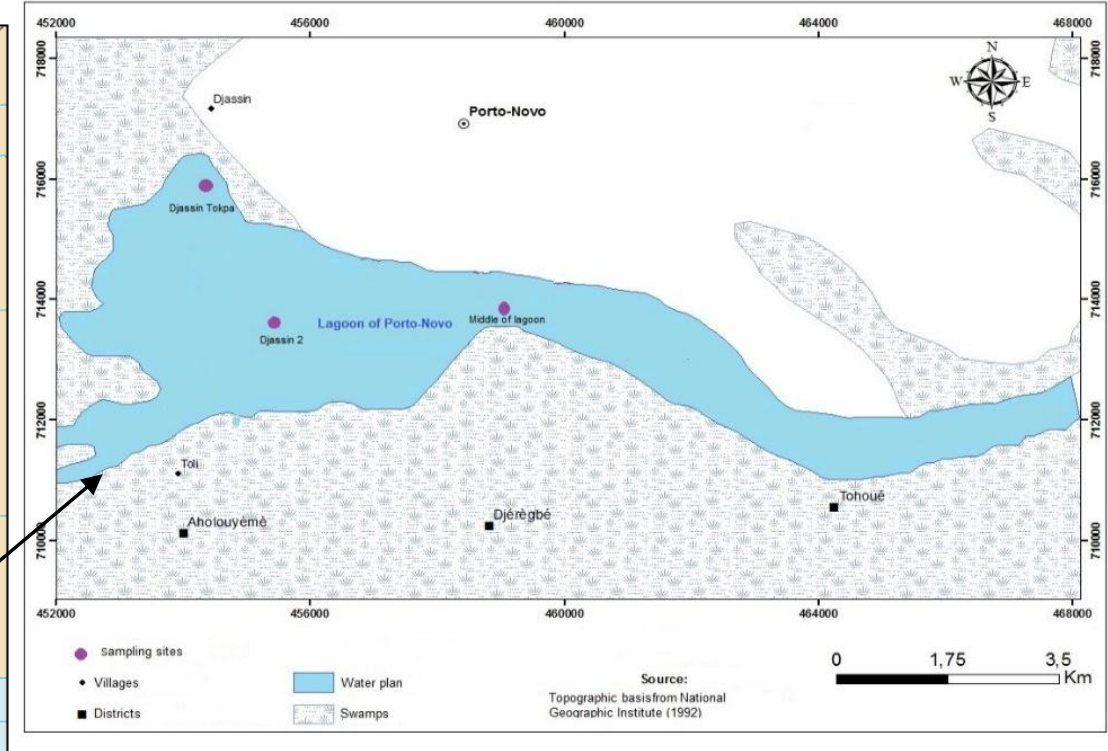

Fig 2:-Sediments and eichornia sampling sites on the lagoon

\section{Samples transportation and analysis}

For transportation, the samples were kept frozen using a cooler box with ice packs. The sample handling methodology was based on methods set out by Avenant-Oldewage and Marx (2000). The samples were then analysed for various metals using standardised methods recognised by the French Association for Standardization (AFNOR) (Rodier, 2009). Samples are reduced to powder or paste. This paste or powder is incinirated in the muffle furnace at $550^{\circ} \mathrm{C}$ for $24 \mathrm{~h}$. The ash thus obtained is dissolved in $2 \mathrm{cc}$ of $\mathrm{HCl}, 6 \mathrm{~N}$ wich is evaporated on a hotplate at $125^{\circ} \mathrm{C}$. The more or less viscous residue obtained is again dissolved and recoverded with $\mathrm{HNO}_{3}, 0.1 \mathrm{M}$ in flask of $100 \mathrm{cc}$ or $50 \mathrm{cc}$. The solution thus obtained is used, after dilution or not to meseasure metals by atomic absorption spectrophotometry (AAS). 


\section{Results and discussion:-}

Results are provided as mg per kg dry weight of each element.

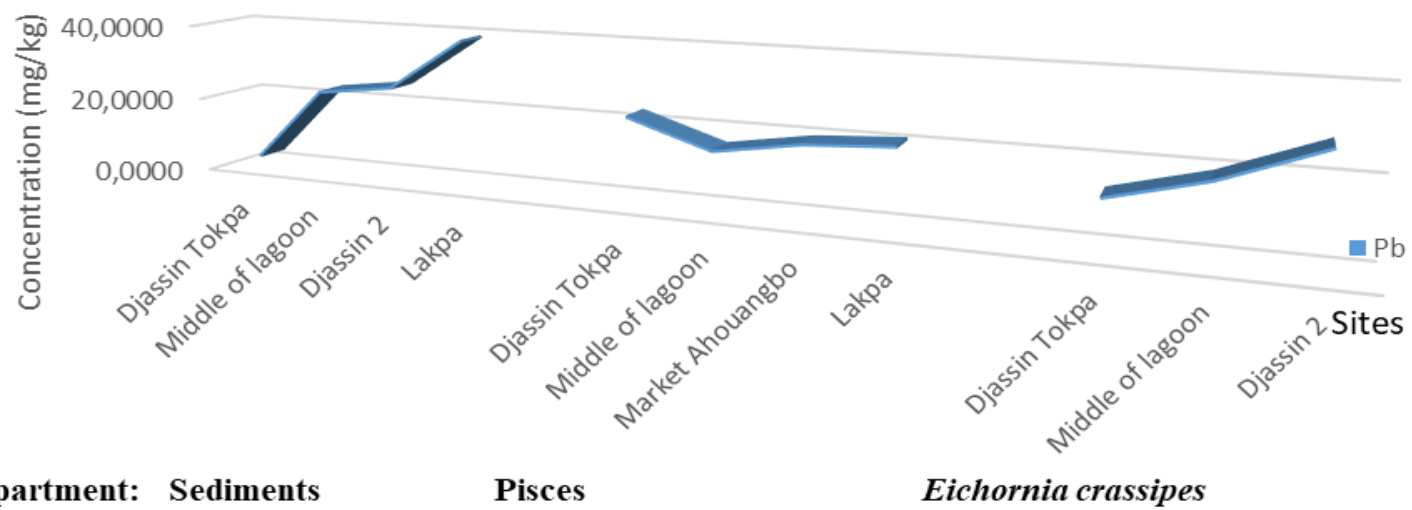

Fig 3: Comparaison of Pb concentration according to the compartment of hydro-system

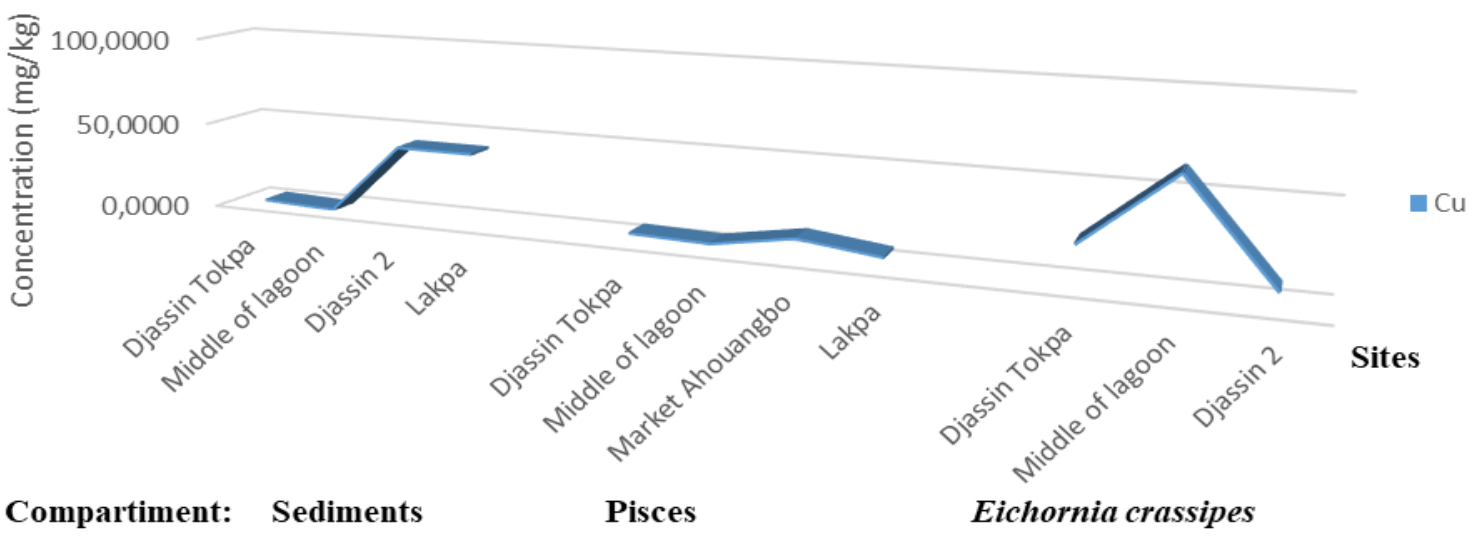

Fig 4 : Comparaison of $\mathrm{Cu}$ concentration according to the compartments of hydro-system

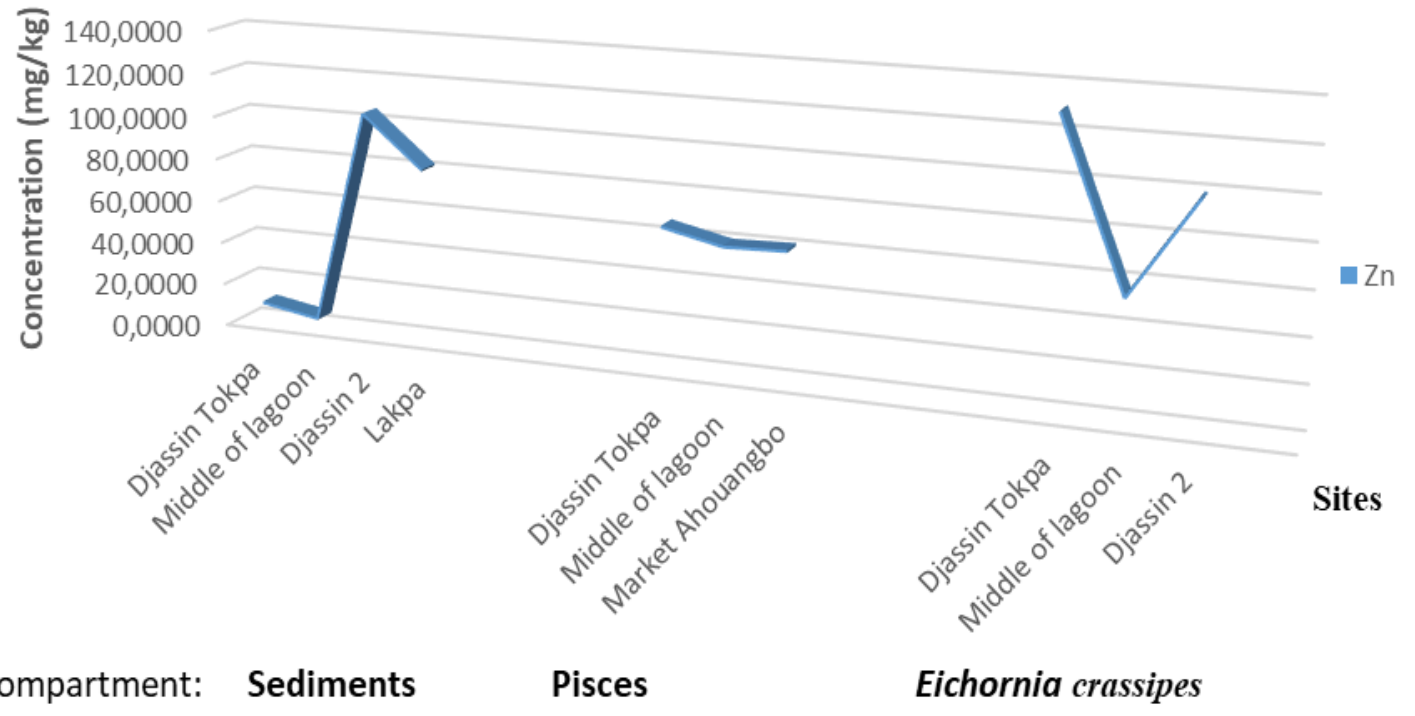

Fig 5: Comparaison of $\mathrm{Zn}$ concentration according to the compartments of hydro system 


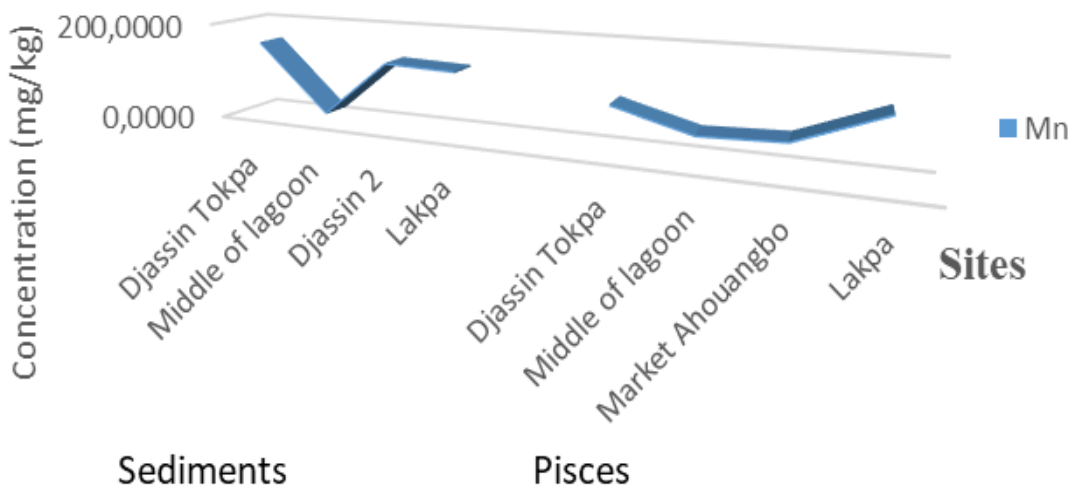

Fig 6: Comparaison of Mn concentraion in sediments and in fish by sites

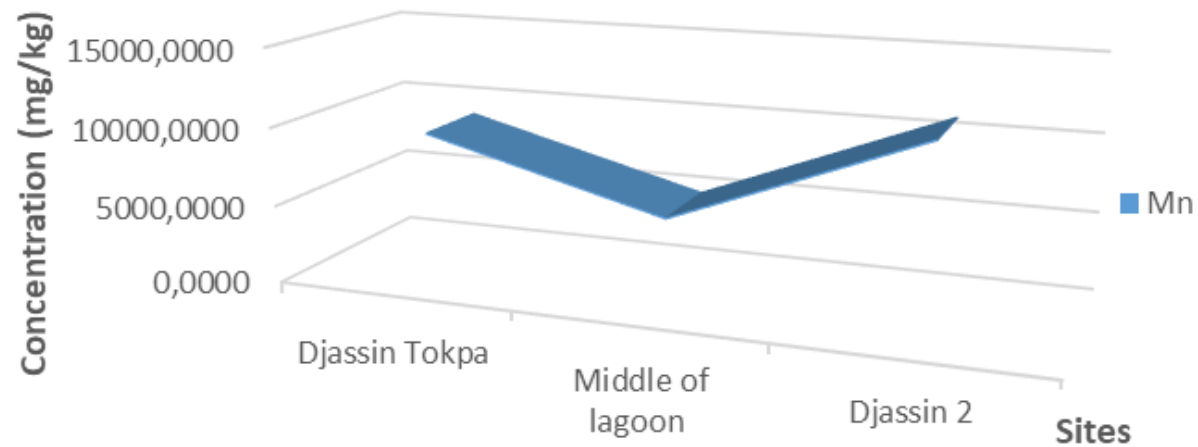

Fig 7: Concentration of $\mathrm{Mn}$ in eichornia crassipes by site on the lagoon

Metallic elements are normally present at low level in soils, sediments, surface waters and living organisms (Holmstrom, 2000). This constitues the geochemical background of a certain environment (Canada, 2012). Metals are present at various concentrations in pisces, eichornia crassipes and sediments across the different sites. Values obtained in this study are ranged as followed:

In sediments

\begin{tabular}{|c|c|}
\hline Trace Metallic Element & Range (mg/kg) \\
\hline $\mathrm{Pb}$ & $3,2-39,17$ \\
\hline $\mathrm{Mn}$ & $18,18-158,19$ \\
\hline $\mathrm{Cu}$ & $0,46-41,6$ \\
\hline $\mathrm{Zn}$ & $5,11-104,82$ \\
\hline
\end{tabular}

Table 1:-Range of trace metallic element values in sediments

Metallic trace elements concentrations associated with sediment are at least three orders of magnitude greater than the same element in the aqueous phase, in part because fine-grained sediment is a transport agent for trace elements that coat particle surfaces or are adsorbed.The use of streambed-sediment analysis provides an understanding of the fate and distribution of MTE.

The values recorded for this study are low than these obtained by Djedi (2018) in Algeria and higher than thoses published by Serpaud (1994) in France. The lead concentration at Lakpa is the most high and the lowest is recorded at Djassin Tokpa. The higher concentratrations are also obtained at Lakpa and Djassin 2 for $\mathrm{Cu}$, two sites where anthropic activities effects are important. 
For $\mathrm{Zn}$ the most high values are obtained at Djassin 2, then at Lakpa and the highest concentration for Mn is recorded at Lakpa. The results of this study are in harmony with those of Chouti (2010) for $\mathrm{Pb}$ and $\mathrm{Mn}$ on the same lagoon.

The sediment constitues the main compartment for metal storage in aquatic environment. The fine fraction of sediments is wich concentrates metals because of its large area (Bril, 2001). For stream sediment, the background sites represent sites of minimal anthropogenic activity during the early stages of reservoir development and are used to distinguish between naturally occurring concentrations and anthropogenic contamination (Obodo, 2004).The erosion of the earth's crust can enrich strems with metallic elements but the high values obtained at the Lakpa site can be explained by the presence of pesticide residues in water and sediments.

In fact, rice cultivation is practiced in the watercourse and among others, maize, cassava, beans and oil palm are grown on the land. The relief of the site is also sloping and facilitates the transport of these residues of pesticide in the water and the sediments by streaming.

\section{In pisces}

\begin{tabular}{|c|c|}
\hline Trace metallic element & Range (mg/kg) \\
\hline $\mathrm{Cu}$ & $4,5-11,2$ \\
\hline $\mathrm{Mn}$ & $18,60-94,7$ \\
\hline $\mathrm{Pb}$ & $14,8-22,8$ \\
\hline $\mathrm{Zn}$ & $48,95-65,6$ \\
\hline
\end{tabular}

Table 2 :-Range of trace metallic element values in pisces

Tilapia is an omnivorous species being larvivorous during its juvenile stages and herbivorous as adults. Although this species is not part of the higher trophic levels, it has been found to accumulate metals (Obodo, 2004 ; Aderinola, 2012).

The highest values are registred in pisces from Market Ahouangbo (one of the important markets of Porto-Novo) for $\mathrm{Cu}$ and those from Djassin Tokpa for $\mathrm{Zn}, \mathrm{Mn}$ and $\mathrm{Pb}$. The concentrations of four metals are lowest at the middle of lagoon. All of the values exceeded the standards of France Superior Council for Public Hygien (CSHPF) wich are $0,5 \mathrm{mg} / \mathrm{kg}$ for $\mathrm{Pb}, 35 \mathrm{mg} / \mathrm{kg}$ for $\mathrm{Zn}$ and $10 \mathrm{mg} / \mathrm{kg}$ for $\mathrm{Cu}$. Lead is toxic to humans of all ages. Children are more susceptible because they still have developing nervous systems and are commonly exposed during normal-play activities. Once absorbed into an human, lead inhibits the functioning of certain enzymes (often with severe physiological/neurological consequences). So the consumption of pisces with these levels of $\mathrm{Pb}$ presents risks for human health. However the results of table 2 are in harmony with those obtained by Kayalto (2009) in Chad but higher than these recorded by Chaid in Maroc (Chaid, 2016) for Pb. For Mn the values obtained are highest than 1,5 $\mathrm{mg} / \mathrm{Kg}$ wich is the standard for Australia New Zealand Food Authority(ANZFA, 1996). In comparaison with the values obtained in Nigeria for three rivers (Benue, Anambra and Badagry) all of concentration are high than those recorded by Eneji and al (2011), Obodo (2014) and Aderinola (2012) for the four metals. However there are in harmony for $\mathrm{Pb}$ and $\mathrm{Mn}$, with those obtained by Tate (2014) in Badeni river in Cote d'Ivoire but low than those registred for $\mathrm{Zn}$ and $\mathrm{Cu}$ in the same river.

In eichornia crassipes

\begin{tabular}{|c|c|}
\hline Trace metallic element & Range $(\mathrm{mg} / \mathrm{kg})$ \\
\hline $\mathrm{Pb}$ & $13,01-28,01$ \\
\hline $\mathrm{Mn}$ & $5235,22-11335,6813$ \\
\hline $\mathrm{Cu}$ & $8,36-62,38$ \\
\hline $\mathrm{Zn}$ & $54,58-129,72$ \\
\hline
\end{tabular}

Table 3 :-Range of trace metallic elements values in eichornia crassipes

For severals years research have been conducded on the accumulation of trace metallic element (TME) by macrophytes and reveal that some of aquatic plants have interessant capacity of bioaccumulation. So, most of TME as $\mathrm{Pb}, \mathrm{Cu}, \mathrm{Zn}$ and $\mathrm{Mn}$ can be accumulated by them. 
This study shows the higher values in eichornia crassipes at Djassin 2 for $\mathrm{Pb}$ and $\mathrm{Mn}$, at middle of Lagoon for $\mathrm{Cu}$ and at Djassin Tokpa for $\mathrm{Zn}$. Concentrations recorded for the four metals studyed reveal that eichornia crassipess is an important biaccumulator of TME especially Mn.

\section{Conclusion:-}

Metal elements are normally present at low level in soils, sediments, surface waters and living organisms (Ljungberg, 2018). The purpose of the present study was to determine the extent of metal pollution in Lagoon of Porto-Novo.

Levels of lead, manganese, copper and zinc in sediments, pisces and eichornia crassipes from lagoon are very important and fish from the lagoon had high metal content and can present risk for human consumption.Due to values obtained for TME analysed at Lakpa and at some sites on the lagoon where anthropic activities such as discharge of waste water and solid wastes are intense, we can link lagoon pollution to these activities and argue that metal pollution at Lakpa is related to agricultural activity using fertilizers and pesticides

The comparison of TME values obtained in the present study with levels of those found elsewhere suggests that there are reasons to take awareness and alarm local authorities about the situation.

\section{Bibliographical references:- \\ Newspapers}

1. Teta C, Ncube M, Naik Y S. 2017. Heavy metal contamination of water and fish in peri-urban dams around Bulawayo, Zimbabwe. African Journal of Aquatic Science. 42(4): (2017) 351-358.

2. Sirima O, Toguyeni Aand Kabore-Zoungrana C.2018.Fish fauna of the Comoé bassin and growth parameters of some species of economic interest International Journal of Biological and Chemical Sciences in Achoh M. E., Agadjihouede H, Gangbe L, Dougnon V T and Baba-Moussa L.Diversity and abundance of tilapia fish exploited in Benin and virus TiLV (Tilapia Lake virus) : Summary review and prospection of the explosion risks of the de l'épidémic. Afrique Science 14(2) (2018) 90-99.www.afriquescience.info

3. Canonico G C, Arthington A, Mccrary JK and Thieme M L.2005. The effects of introduced tilapias on native biodiversity. Aquatic Conservation Marine and Freshwater Ecosystems, 15 (2005) 463-483.

4. Avenant-Oldewage A, Marx HM. 2000. Bioaccumulation of chromium, copper and iron in the organs and tissues of Clarias gariepinus in the Olifants River, Kruger National Park .Water SA 26: (2000) 569-582.

5. Kayalto B C. 2009. Contribution to the assessment of heavy metal contamination, three fish species, sediments and Lake Chad waters. https://hal-auf.archives-ouvertes.fr/hal-00825482

6. Eneji IS, Ato RS, Annune PA. 2011. Bioaccumulation of heavy metals in fish (Tilapia zillii and Clarias gariepinus) organs from River Benue, north-central Nigeria. Pakistan Journal of Environmental Chemistry 1: (2011)25-31.

7. Obodo GA. 2004. The bioaccumulation of heavy metals in fish from Anambra River. Journal of Chemistry Society of Nigeria 29: (2004) 60-63.

8. Aderinola OJ, Kusemiju V, Clarke EO, Anetekhai MA, Adu AA. 2012. Bioaccumulation of heavy metals in silver catfish Chrysichthys nigrodigitatus, Tilapia zillii and Macrobrachuim macrobrachion caught in Badagry Creek, Lagos Nigeria. Transnational Journal of Science and Technology 2: (2012)34-47.

9. Tate R and Husted A. 2014.Bioaccumulation of metals in Tilapia zillii from Badeni Dam, Côte d'Ivoire.African Journal of Aquatic Science 39(2) (2014) 199-202.

10. Djeddi H, Nacereddine S K, D. Keddari, Afri-Mehennaoui F Z. 2018.Levels of $\mathrm{Cu}, \mathrm{Zn}$ and $\mathrm{Pb}$ metallic trace elements in the Beni Haroun dam sediments (North-East Algeria). European Scientific Journal.(2018) Vol 14 No 15.

11. Serpeaud B, Alshukry R, Casteigeau M and Matejka G.1994. Heavy metal adsorption (Cu, Zn, Cd and Pb)by superficial stream sediments : effects of $\mathrm{pH}$, temperature and sediment composition. Water Science Jounal. 7 (1994) 343-365

12. Varkouhi S. Lead Contamination of Streambed Sediments in Veysian River Basin, Lorestan Province, Iran. Department of Geology Islamic Azad University, Khorram Abad Branch, Khorram Abad, Lorestan IRAN. Water and Geoscience, ISBN: 978-960-474-160-1, pp 144-147. 
13. Chouti W, Mama D, Changotade O, Alapini F, Boukari M.2010.Study of the metallic traces elements contained in the sediments of the lagoon of Porto-Novo (South Benin).Journal of Applied Biosciences 34: (2010) 2186 2197.

14. Oussama L .2014. Contribution to the assessment of manganese and iron contents in surface water sediments: the case of wadis in the Rhumel-Seguen and Rhumel-Smendou sub-basins. Final thesis to obtain the Master II degree. Constantine University 1, Algeria.

15. ThesisChaguer M. 2013. Analysis and Speciation of Metals in a Wadi in Mining Zone. Case of Oued Essouk. Doctoral thesis. University of Constantine I. Algeria. 146p

16. Adeline A. 2011. Metallic decontamination and recovery capacities of two biological components of a natural hydrosystem - diatomic biofilms and filter bivalves after remediation of an industrial site, $\mathrm{PhD}$ Thesis, University Bordeaux 1. 378p.

17. Chaid A.2016.Quantification of metallic trace elements (cadmium, lead and total mercury) of certain fishery products landed in the Essaouira-Dakhla zone: Health risk assessment. Doctoral thesis. Ibn Zohr University. Agadir. Morocco.

18. BooksBril H, Floc'h JP. 2001. The fate of metals from old mines - The example of the French central massif, "Géologues",N 130/131, pp : $233-241$

19. Ljungberg H J and Ohlander B. 2000. The character of the suspended and dissolved phases in the water cover of the flooded mine tailings at Stekenjokk, northern Sweden. Science of The Total Environment, 247, N ${ }^{\circ}$, pp : 15-31.

20. Site environnement Canada, 2012. www3.ec.gc.ca. Aquamin: Assessment of the Effects of Mining on the Aquatic Environment in Canada.

21. Leveque C. and Paugy D. 2006.African continental waters fishes: Diversity, Ecology, Human being use. (2006). IRD, Paris.

22. Rodier J.2009. Analysis of water: natural water, wastewater, sea water technical Dunod. 9th edition, Paris, p 709-712. 